\title{
EVALUATING OF SOME QUALITY PARAMETERS OF DIFFERENT APRICOT CULTIVARS USING HPLC METHOD
}

\author{
K. DOLENC-ŠTURM, F. ŠTAMPAR and V. USENIK \\ Institute for Fruit Growing, Viticulture and Vegetable Growing, Agronomy Department, Biotechnical \\ Faculty, Jamnikarjeva 101, SLO-1111 Ljubljana. Slovenia
}

(Received: 27 January 1999; accepted: 23 june 1999)

\begin{abstract}
High performance liquid chromatography (HPLC) was used for separation, identification and quantification of sugars, sugar alcohol sorbitol and non-volatile acid content in puree of 15 apricot cultivars (Prunus armeniaca L.). Sugar analyses included sucrose, glucose, fructose, xylose and sorbitol. The main organic acids characterizing apricot puree are malic, citric and fumaric acid. Variation in the content of the analyzed compounds mentioned and also in the content of soluble solids (SS), titratable acids and $\mathrm{pH}$ value was found among the cultivars.

Sensory evaluation showed that the content of individual organic acids and sugars as well as their relations could be crucial in forming the taste.

Knowledge of the qualitative and quantitative composition of acids and sugars in apricot fruits may prove to be a powerful tool in evaluating fruit maturity and quality.
\end{abstract}

Keywords: apricot (Prunus armeniaca L.), organic acids, sorbitol, sugars

Fruits represent an important and rich compound of healthy nutrition and are vital for human's health, well being and active life style. Fruits are generally high in dietary fiber and low in fats and oils, and are therefore important in diets that are designed to reduce the risk of coronary heart disease.

Stone fruits have long been appreciated for their gustatory and aesthetic qualities. In spite of these characteristics, they have not been highly favored as specimens in biochemical research. Nowadays, new chemical analyses allow a specific and objective determination of the content of individual substances in fruit of different varieties. Subjective estimations, which have been used to evaluate the quality of fruits from the visual aspect to sensory characteristics, are thus supplemented. Taste of an edible product, which is perceived by specialized taste buds on the tongue, represents one of the quality attributes consumers try to correlate with visual parameters of the products. Before the introduction of new apricot varieties in extensive production, growing and pomological characteristics have to be evaluated, because some important characteristics of varieties might depend on the environment. Of the many factors that 
can affect the taste quality of a product, cultivar, ripeness, maturity, irrigation and fertilization are especially important.

The content of soluble solids, free sugars, organic acids, minerals, vitamins, etc., fruit colour, taste and firmness of fruit depends on the activity of photosynthesis and the use of its products (FAUST, 1989). These compounds are common indicators of metabolic activity (HUDINA \& ŠTAMPAR, 1998) or may indicate changes in quality, since sensory changes often accompany changes in organic acids, sugars and alcohol (DOYON et al., 1991). Chromatographic investigations of sugars and organic acids in different fruits were made by RICHMOND and co-workers (1981), of apricot cultivars by KOVÁCS and DJEDRO (1994) and by LO VOI and co-workers (1995), of raspberry cultivars by RIAZ and BUSHWAY (1994), of peach genotypes by BROOKS and co-workers (1993), of cherry cultivars by DOLENC and STAMPAR (1998) etc. High performance liquid chromatography (HPLC) is often the method of choice in quality control laboratories when analyzing for sugars (FöLDHÁZI, 1994), sugar alcohols and organic acids. Recently, due to such advantages as rapidity, reliability, sensitivity and costeffectiveness the method has been of increasing interest in the analysis of food constituents (MACRAE, 1981).

The modern industry relies on a rather narrow array of cultivars that are characterized by the size, firmness and eye appeal, and standards necessary for successful marketing. Consumers concern about poor taste is also increasing in certain European markets. Descriptions of end results, e.g. changes in soluble solids, colour and firmness of the fruit are of interest and value to the management of orchards (ROMANI \& JENNINGS, 1971). BASSI and SELLI (1990) suggest two possible ways to improve fruit quality in apricots: developing new genotypes that express the flavour and taste before the fruit becomes too soft, and enhancing flavour in cultivars with firm fruits that never reach a satisfactory quality even fully ripe. The search for maturity indices results from the recurrent need to decide when fruits should be harvested. Knowledge of the qualitative and quantitative composition of acids and sugars in fruits may prove a powerful tool in evaluating fruit maturity and quality (MOLNÁR-PERL \& MORVAI, 1992).

This paper presents the amount of total and individual sugars, titratable acids and individual acids in apricot fruits of different cultivars. Those results could be used together with optical measurements (i.e. fruit size, firmness, skin and mesocarp colour) to determine inner fruit quality, which is especially important for the popularity of individual cultivars by consumers being the aim of every fruit grower. 


\section{Materials and methods}

Pomological characteristics were determined for 15 apricot cultivars: 'Laycot', 'Palummella', 'Pellecchiella', 'Tomcot', 'Hargrand', 'Icapi', 'Aurora', 'Bella d'Imola', 'Giada' 'Dulcinea', 'Harcot', 'Goldrich', 'Perla', 'Orange Red' and 'Sabbatani'. Apricots sampled on the location Stara Gora in the Fruit Growing Center Bilje were analysed at the Institute for Fruit Growing, Viticulture and Vegetable Growing of Biotechnical Faculty in 1998.

Apricots have been picked in identical conditions, at stage called "commercial maturity", i.e., when they are still having $10 \%$ of remaining green colour localized at stitch point.

Five fruits per cultivar were separately evaluated for aroma, sweet/sour ratio and eating quality by five panelists. Aroma and eating quality were assessed according to IBPGR (1984) apricot descriptors, where eating quality is a combined assessment of flavour, acidity, sweetness, aroma and astringency. From the results obtained a modus was calculated for each parameter.

\subsection{Chemical and physical analyses}

High performance liquid chromatography method was used for separation, identification and quantification of individual compounds in apricot puree. The HPLC system consisted of Thermo Separation Products (TSP) equipment with a model P1000 pump, autosampler model AS1000, column heater and OS/2 Warp IBM Operating system (1994)-work station. Solute elution was monitored using a variable wavelength UV detector set at $210 \mathrm{~nm}$ and differential refractive index RI (model Shodex-71RI).

Samples for sugar determination (glucose, fructose, sucrose, xylose and sorbitol) and organic acids (malic, citric and fumaric) determination were prepared from $1.5 \mathrm{~kg}$ of fresh apricots and then divided into three subsamples. They were converted into pulp individually by a mixer and homogenized with Ultra -Turrax T-25 (Ika-Labortechnik). The fruit puree $(10 \mathrm{~g})$ was diluted to $50 \mathrm{ml}$ of bidistilled water and clarified by centrifugation at $6000 \mathrm{~g}$ for $15 \mathrm{~min}$. The extract was filtered through $0.45 \mu \mathrm{m}$ Millipore filters and a $20 \mu \mathrm{l}$ sample was used for HPLC analysis of sugars and organic acids.

Sugars and sugar alcohol sorbitol analyses were performed isocratically on Aminex HPX-87C cartridge at a flow rate of $0.6 \mathrm{ml} \mathrm{min}^{-1}$ at a temperature of $85{ }^{\circ} \mathrm{C}$ with bidistilled and on-line degassed water used as eluent. Attenuation of the refractive index detector was set at 16x. Sugars present in each sample were identified by comparison of the retention time of each peak with those of standard sugars. The concentration of each sample was calculated by comparison of peak areas to the area of calibrated sugar solutions of known concentrations. The reproducibility of the chromatographic separation of the components was determined by making six injections 
of the standard solutions and apricot sample. The results expressed as relative standard deviation (RSD\%) are as follows: 0.29 for sucrose, 0.27 for glucose, 0.28 for fructose and 0.26 for sorbitol.

Organic acids were determined by HPLC analysis using an Aminex HPX-87H column, containing a $9 \mu \mathrm{m}$ particle size, thermostated at $65^{\circ} \mathrm{C}$, which separates organic acids using primarily ion exclusion and reversed phase mechanisms. Using diluted $4 \mathrm{mmol}$ sulfuric acid as eluent; organic acids elute from the column in order of increasing $\mathrm{pK}_{\mathrm{a}}$. Organic acids were identified and quantified by using a UV detector with wavelength set at $210 \mathrm{~nm}$ and by comparison of retention times and peak areas with standard solutions of known organic acids. Results of reproducibility study of chromatographic separation for organic acids expressed as relative standard deviation (RSD\%) are as follows: 0.30 for malic acid, 0.31 for citric acid and 0.13 for fumaric acid.

A value for total acidity, expressed as malic acid monohydrate, was obtained by titrating a $10 \mathrm{~g}$ fresh sub-sample blended with distilled water $(100 \mathrm{ml})$ to end-point $\mathrm{pH}$ 8.1 with $0.1 \mathrm{~N} \mathrm{NaOH}$. The soluble solids, expressed as Brix degrees, were determined in the juice of each sample using a refractometer at $20^{\circ} \mathrm{C}$.

\subsection{Standard materials}

Standards for sucrose, glucose, fructose, xylose and sorbitol as well as citric and fumaric acids were obtained from Fluka Chemical (New York, NY, U.S.A.). Malic acid was obtained from Merck Chemicals (Darmstadt, Germany).

Linearity of the response to UV and RI detection was tested for each compound with five different concentrations prepared in bidistilled water and all correlation coefficients were in the required range.

\section{Results}

The results (modus) of testing panel of tested apricot cultivars are presented in Table 1.

Fruits rich in aroma were those of cvs. 'Palummella', 'Pellecchiella', 'Laycot', 'Harcot' and 'Tomcot'. Fruits of cvs. 'Orange Red' and 'Perla' had little aroma, whereas the fruits of other cultivars demonstrated aroma of intermediate quality.

Fruits of 'Orange red' cultivar were very sweet but without the desired acid, whereas cultivar 'Sabbatani' demonstrated distinctly sour fruits. The best eating quality resulting from a combined assessment of flavour, acidity, sweetness, aroma and astringency was demonstrated by cvs. 'Laycot', 'Palummella' and 'Pellecchiella'. 
Table 1

Results of testing panel of aroma, sweetness/sourness and eating quality of tested apricot cultivars

\begin{tabular}{lccc}
\hline & Aroma & Sweetness/sourness & Eating quality \\
\hline Laycot & rich & sweet-sour & excellent \\
Palummella & rich & sweet-sour & excellent \\
Pellecchiella & rich & sweet-sour & excellent \\
Tomcot & rich & sweet-sour & good \\
Hargrand & intermediate & sweet-sour & good \\
Icapi & intermediate & sweet-sour & good \\
Aurora & intermediate & sweet-sour & good \\
Bella D'Imola & intermediate & sweet-sour & good \\
Giada & intermediate & sweet-sour & good \\
Dulcinea & intermediate & sour-sweet & good \\
Harcot & rich & sour-sweet & fair \\
Goldrich & intermediate & sour-sweet & fair \\
Perla & little & sour-sweet & fair \\
Orange Red & little & sweet & fair \\
Sabbatani & intermediate & sour & \\
\hline
\end{tabular}

Table 2

The content of sugars and sorbitol in apricot puree

\begin{tabular}{|c|c|c|c|c|c|}
\hline & $\begin{array}{c}\text { Sucrose } \\
(\mathrm{g} / \mathrm{kg})\end{array}$ & $\begin{array}{l}\text { Glucose } \\
(\mathrm{g} / \mathrm{kg})\end{array}$ & $\begin{array}{l}\text { Fructose } \\
(\mathrm{g} / \mathrm{kg})\end{array}$ & $\begin{array}{c}\text { Xylose } \\
(\mathrm{g} / \mathrm{kg})\end{array}$ & $\begin{array}{c}\text { Sorbitol } \\
(\mathrm{g} / \mathrm{kg})\end{array}$ \\
\hline Laycot & 66.0 & 29.0 & 13.4 & 5.0 & 6.1 \\
\hline Palummella & 55.2 & 37.3 & 12.3 & 3.6 & 0.8 \\
\hline Pellecchiella & 74.1 & 28.1 & 14.0 & 4.8 & 6.4 \\
\hline Tomcot & 61.4 & 30.5 & 14.8 & 4.7 & 5.2 \\
\hline Hargrand & 79.8 & 31.9 & 11.0 & 5.5 & 5.2 \\
\hline Icapi & 65.8 & 32.4 & 20.5 & 1.5 & 2.0 \\
\hline Aurora & 43.4 & 23.9 & 6.4 & 0.4 & 0.2 \\
\hline Bella D’Imola & 34.5 & 34.2 & 13.4 & 7.4 & 2.9 \\
\hline Giada & 58.6 & 29.1 & 12.7 & 1.4 & 0.4 \\
\hline Dulcinea & 65.1 & 35.1 & 15.4 & 5.0 & 10.2 \\
\hline Harcot & 79.5 & 22.7 & 10.1 & 5.6 & 4.8 \\
\hline Goldrich & 63.5 & 31.1 & 12.9 & 4.7 & 2.4 \\
\hline Perla & 45.3 & 36.5 & 14.6 & 4.3 & 0.3 \\
\hline Orange Red & 54.9 & 35.4 & 17.5 & 4.3 & 2.8 \\
\hline Sabbatani & 45.3 & 35.2 & 11.7 & 5.8 & 2.6 \\
\hline $\min$. & 34.5 & 22.7 & 6.4 & 0.4 & 0.2 \\
\hline average & 59.5 & 31.5 & 13.4 & 4.3 & 3.5 \\
\hline $\max$ & 79.8 & 37.3 & 20.5 & 7.4 & 10.2 \\
\hline STD & 13.3 & 4.4 & 3.2 & 1.9 & 2.8 \\
\hline
\end{tabular}




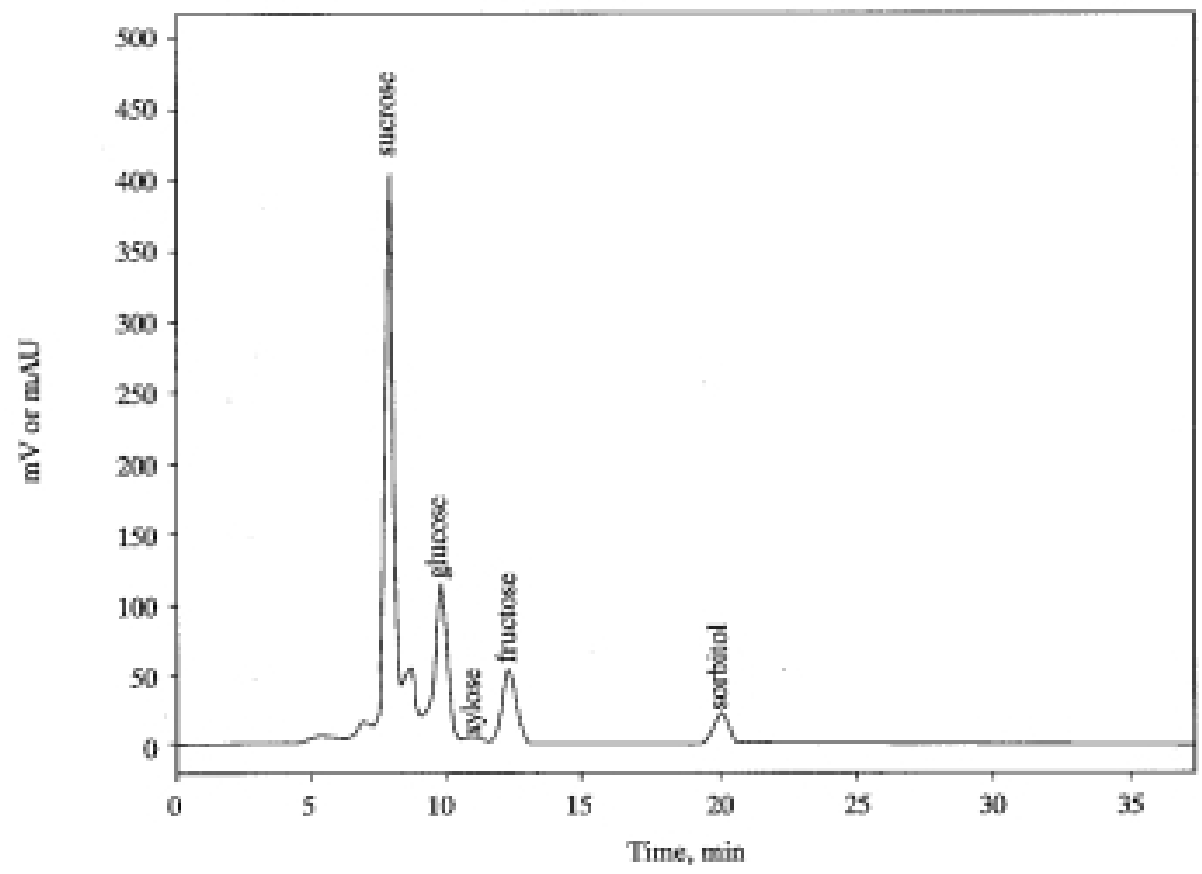

Fig. 1. Chromatographic separation of sugars in apricot puree. Column: Aminex HPX-87C $(300 \times 7.8 \mathrm{~mm})$; column temp. $85^{\circ} \mathrm{C}$; mobile phase: BD water; flow rate $0.6 \mathrm{ml} \mathrm{min}{ }^{-1}$, refractive index detector

The analytical data on the carbohydrate fraction of 15 apricot cultivars are presented in Table 2. Each value is a mean of three measurements (one measurement per subsample). The content of sucrose in analyzed samples varied from $34.5 \mathrm{~g} / \mathrm{kg}$ with cv. 'Bella d'Imola' to 79.5 and $79.8 \mathrm{~g} / \mathrm{kg}$ in cvs. 'Harcot' and 'Hargrand', respectivelly. The variability in the content of glucose ranges from $22.7 \mathrm{~g} / \mathrm{kg}$ with cv. 'Harcot' to $37.3 \mathrm{~g} / \mathrm{kg}$ in cv. 'Palummella' with a mean of $31.5 \mathrm{~g} / \mathrm{kg}$ for the different cultivars tested. The amount of fructose in the apricot puree varied from $6.4 \mathrm{~g} / \mathrm{kg}$ in cv. 'Aurora' to $20.48 \mathrm{~g} / \mathrm{kg}$ in cv. 'Icapi' with a mean value of $13.4 \mathrm{~g} / \mathrm{kg}$. Xylose content is also very variable; its range is from $0.4 \mathrm{~g} / \mathrm{kg}$ to $7.4 \mathrm{~g} / \mathrm{kg}$, with an average value of $4.3 \mathrm{~g} / \mathrm{kg}$.

The content of sugar alcohol sorbitol was extremely low in cultivars 'Aurora', 'Perla' and 'Giada', whereas the content of sorbitol in cv. 'Dulcinea' was $10.2 \mathrm{~g} / \mathrm{kg}$. Normally, with larger amount of soluble solids in apricot cultivars, the content of individual sugars and especially sorbitol, increased too.

Figure 1 shows the chromatogram of sugars in apricot puree. 
The analytical data on individual organic acids, total acidity $(\mathrm{g} / \mathrm{kg})$ and $\mathrm{pH}$ value of apricot puree are presented in Table 3. Each value is a mean of three measurements (one measurement per subsample). Malic acid content varied from $10.9 \mathrm{~g} / \mathrm{kg}$ in cultivar 'Pellecchiella' to $32.6 \mathrm{~g} / \mathrm{kg}$ in cultivar 'Aurora'. The mean value was $18.9 \mathrm{~g} / \mathrm{kg}$. The citric acid content was from 0.5 in cv. 'Sabbatani' and 0.6 in cv. 'Aurora' to $20.3 \mathrm{~g} / \mathrm{kg}$ in 'Laycot' with an average value of $11.6 \mathrm{~g} / \mathrm{kg}$.

The average value of fumaric acid was $16.8 \mathrm{mg} / \mathrm{kg}$, with the lowest content in cultivar 'Laycot' $(9.9 \mathrm{mg} / \mathrm{kg})$ and the highest content in cv. 'Perla' $(30.0 \mathrm{mg} / \mathrm{kg})$. Mean value for total acidity in apricot puree was $37.6 \mathrm{~g} / \mathrm{kg}$. The highest content of free acids was obtained in cvs. 'Aurora' and 'Bella d'Imola' and the lowest content of free acids were in cvs. 'Icapi' and 'Orange Red'. The mean $\mathrm{pH}$ value for analyzed apricot puree was 3.6, with a lower value 3.2 in 'Aurora' and upper value 3.9 in cultivar 'Pellecchiella'.

Table 3

The content of organic acids, $\mathrm{pH}$ value and total acidity in apricot puree

\begin{tabular}{|c|c|c|c|c|c|}
\hline & $\begin{array}{l}\text { Malic acid } \\
\quad(\mathrm{g} / \mathrm{kg})\end{array}$ & $\begin{array}{l}\text { Citric acid } \\
(\mathrm{g} / \mathrm{kg})\end{array}$ & $\begin{array}{l}\text { Fumaric acid } \\
\qquad(\mathrm{mg} / \mathrm{kg})\end{array}$ & $\mathrm{pH}$ value & $\begin{array}{c}\text { Total acidity } \\
(\mathrm{g} / \mathrm{kg})\end{array}$ \\
\hline Laycot & 14.3 & 20.3 & 9.9 & 3.5 & 44.3 \\
\hline Palummella & 18.9 & 14.7 & 21.3 & 3.3 & 43.2 \\
\hline Pellecchiella & 10.9 & 16.3 & 20.6 & 3.9 & 30.4 \\
\hline Tomcot & 15.8 & 17.8 & 12.8 & 3.6 & 40.9 \\
\hline Hargrand & 18.1 & 9.9 & 17.7 & 3.8 & 30.3 \\
\hline Icapi & 11.0 & 11.0 & 16.2 & 3.5 & 24.6 \\
\hline Aurora & 32.6 & 0.6 & 13.3 & 3.2 & 54.3 \\
\hline Bella D'Imola & 30.8 & 6.5 & 18.6 & 3.3 & 50.0 \\
\hline Giada & 15.4 & 11.0 & 19.9 & 3.7 & 31.1 \\
\hline Dulcinea & 18.4 & 16.7 & 12.8 & 3.5 & 41.3 \\
\hline Harcot & 21.4 & 14.6 & 12.7 & 3.5 & 39.3 \\
\hline Goldrich & 16.4 & 15.4 & 17.0 & 3.5 & 42.5 \\
\hline Perla & 16.6 & 7.2 & 30.0 & 3.7 & 27.6 \\
\hline Orange Red & 15.5 & 12.2 & 16.3 & 3.8 & 26.9 \\
\hline Sabbatani & 27.7 & 0.5 & 12.2 & 3.4 & 36.6 \\
\hline $\min$. & 10.9 & 0.5 & 9.9 & 3.2 & 24.6 \\
\hline average & 18.9 & 11.6 & 16.8 & 3.6 & 37.6 \\
\hline $\max$ & 32.6 & 20.3 & 30.0 & 3.9 & 54.3 \\
\hline STD & 6.8 & 11.6 & 5.0 & 0.2 & 8.8 \\
\hline
\end{tabular}




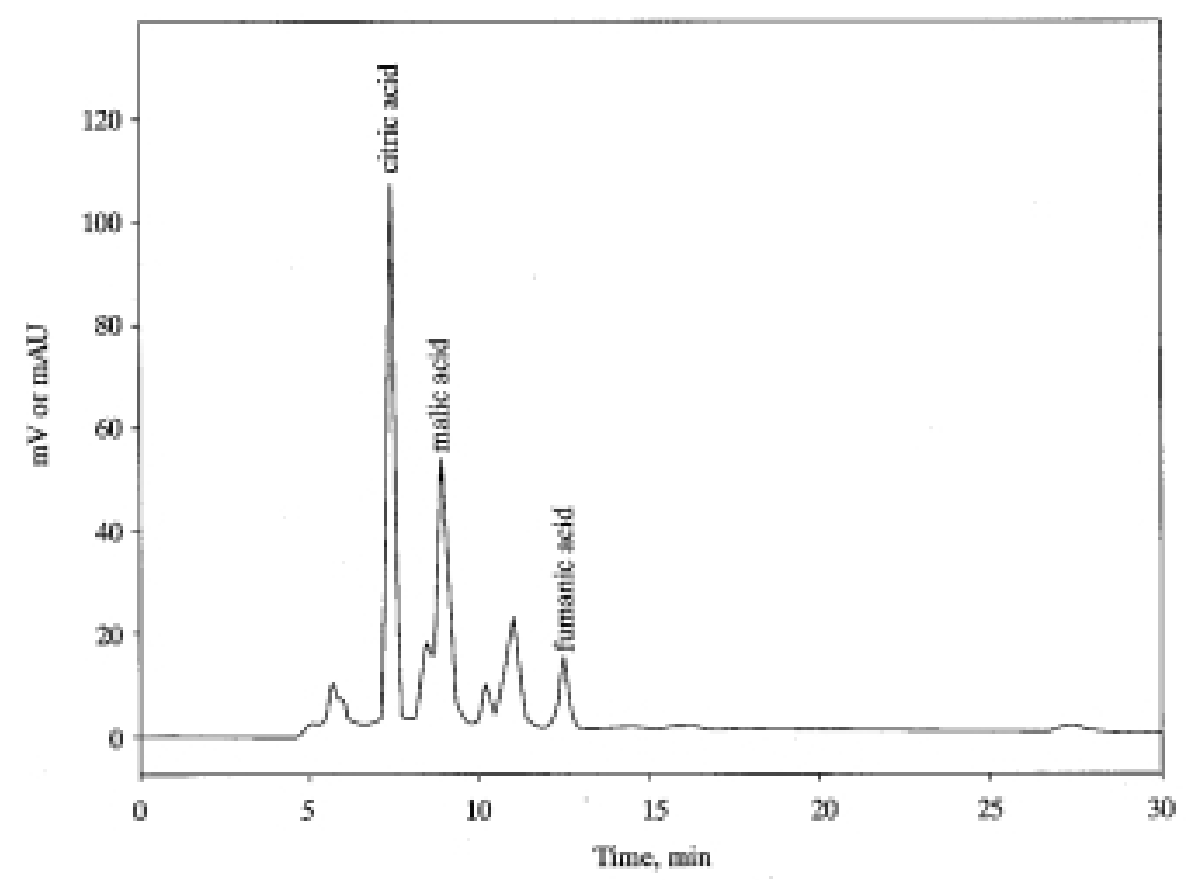

Fig. 2. Chromatographic separation of organic acids in apricot puree. Column: Aminex HPX-87H $(300 \times 7.8 \mathrm{~mm})$; temp. $65^{\circ} \mathrm{C}$; mobile phase: $4 \mathrm{mmol}$ sulphuric acid; flow rate $0.6 \mathrm{ml} \mathrm{min}{ }^{-1}$; UV detector

$$
\text { at } 210 \mathrm{~nm}
$$

Figure 2 shows the chromatogram of organic acids in the apricot puree.

Analytical data on soluble solids (SS), total sugars $(\mathrm{g} / \mathrm{kg})$, glucose/fructose, $\mathrm{Brix} \%$ acidity and malic/citric ratio in apricot puree are reported in Table 4 . The content of soluble solids (SS) of different apricot cultivars was from 10.2 to 18.2 degrees of Brix. Cultivars 'Aurora', 'Giada' and 'Perla', ripening early in June had the lowest content of SS, whereas the cv. 'Dulcinea' had the highest content (18.2 Brix $\left.{ }^{\circ}\right)$ of soluble solids. The average content of soluble solids was $13.8 \mathrm{Brix}^{\circ}$.

The average glucose to fructose ratio of tested cultivars was 2.5 , with the lowest ratio in cv. 'Icapi' and the highest ratio in cv. 'Aurora' (3.7). Those ratios are usually significant for varieties and lower values of that ratio could easily be linked to abnormalities in the storage process. Higher ratios in products can indicate that glucose was added to hide high acidity. The average value of sweet/sour ratio is calculated by dividing the sugar content of fruit, expressed as degrees Brix, by its percentage of acids. 
Table 4

The content of soluble solids (SS), total sugars ( $/ \mathrm{kg})$, glucose/fructose, Brix\%/acidity and malic/citric ratio in apricot puree

\begin{tabular}{lcccccc}
\hline & $\begin{array}{c}\text { SS } \\
\text { Brix }\end{array}$ & $\begin{array}{c}\text { Total } \\
\text { sugars }(\mathrm{g} / \mathrm{kg})\end{array}$ & $\begin{array}{c}\text { Glu./fru. } \\
\text { ratio }\end{array}$ & $\begin{array}{c}\text { Brix/acidity } \\
\text { ratio }\end{array}$ & $\begin{array}{c}\text { Malic/citric } \\
\text { acid ratio }\end{array}$ & $\begin{array}{c}\text { Total acidity/ } \\
\text { malic acid }\end{array}$ \\
\hline Laycot & 15.2 & 119.6 & 2.2 & 3.5 & 0.7 & 3.1 \\
Palummella & 12.2 & 109.1 & 3.0 & 2.8 & 0.8 & 2.3 \\
Pellecchiella & 14.2 & 127.4 & 2.0 & 4.7 & 0.7 & 2.8 \\
Tomcot & 12.6 & 116.6 & 2.1 & 3.1 & 0.9 & 2.6 \\
Hargrand & 17.2 & 133.2 & 3.0 & 5.7 & 1.8 & 1.7 \\
Icapi & 14.6 & 122.2 & 1.6 & 5.8 & 1.0 & 2.2 \\
Aurora & 10.2 & 74.3 & 3.7 & 1.9 & 55.2 & 1.7 \\
Bella D'Imola & 13.6 & 92.4 & 2.6 & 2.7 & 4.7 & 1.6 \\
Giada & 10.2 & 102.2 & 2.3 & 3.3 & 1.4 & 2.0 \\
Dulcinea & 18.2 & 130.7 & 2.3 & 4.4 & 1.1 & 2.2 \\
Harcot & 17.0 & 122.2 & 2.2 & 4.4 & 1.5 & 1.8 \\
Goldrich & 14.2 & 114.6 & 2.4 & 4.6 & 1.1 & 2.6 \\
Perla & 10.2 & 101.1 & 2.5 & 3.6 & 2.3 & 1.7 \\
Orange Red & 12.8 & 144.9 & 2.0 & 4.7 & 1.3 & 1.7 \\
Sabbatani & 14.2 & 100.6 & 3.0 & 3.8 & 53.0 & 1.3 \\
min. & 10.2 & 74.3 & 1.6 & 1.9 & 0.7 & 1.3 \\
average & 13.8 & 107.6 & 2.5 & 3.9 & 8.5 & 2.1 \\
max. & 18.2 & 144.9 & 3.7 & 5.8 & 55.2 & 3.1 \\
STD & 2.5 & 32.2 & 0.5 & 1.1 & 18.5 & 0.5 \\
\hline
\end{tabular}

The Brix $\%$ acid ratio for apricot fruit ranged from 1.9 for cv. 'Aurora' to 5.7 and 5.8 in cvs. 'Hargrand' and 'Harcot', respectively. So low ratio in cv. 'Aurora' is mostly due to low soluble solids content and high total acidity content.

The ratio between the content of malic and citric acid varied from 0.7 in cvs. 'Laycot' and 'Pellecchiella' to 53.0 in cv. 'Sabbatani' and 55.2 in cv. 'Aurora'. Such variability is almost due to high malic acid content in those cultivars. It is interesting that cultivars with low ratio ('Laycot', 'Pellecchiella' and 'Palummella') were very tasteful, whereas the cv. 'Sabbatani' was found to be acidic. The average value for the ratio between total acidity and the content of malic acid was 2.1 , but cultivars with higher values were more appreciated. 


\section{Discussion}

Taste of a fruit is largely determined by a balance between the sugar and acid contents. Low acid and high sugar contents result in a bland taste, and high acid and low sugar contents give a sour taste. The content of soluble solids is the function of several factors of which total sugars and organic acid constitute the major part (SHARMA \& SHARMA, 1990). The average content of soluble solids $\left(13.8 \mathrm{Brix}^{\circ}\right)$ of investigated cultivars was higher in comparison with results of LO VOI and co-workers (1995), who found an average value of 10.6. Sucrose was the major sugar in apricots with glucose and fructose present in higher amounts too, whereas xylose was present as a minor component. Comparison of results with the data of WILLS and co-workers (1983) and LO VOI and co-workers (1995) shows, that sugars (glucose, fructose and sucrose) in analyzed cultivars are present in higher amounts. In addition to the variety influence on the composition of the fruit, weather and nutritional conditions may also affect the concentration of the individual compounds and may cause an increase in sugar and a decrease in acid content, especially in citric acid (RIAZ \& BUSHWAY, 1994).

High accumulation of sugars in the fruit is a result of the direct translocation of sorbitol from nearby leaves (WILLIAMS et al., 1967). Sorbitol is a specific and major translocation carbohydrate in mature apricot leaves (BIELESKI \& REDGWELL, 1985). In fruits it is not accumulated but continuously converted into fructose, sucrose and glucose (ACKERMANN et al., 1992). During the early stages of growth, reducing sugars like glucose and fructose predominate, while sucrose appears at the start of second phase of growth and thereafter increases along with reducing sugars till picking maturity (NIGAM \& SHARMA, 1987). The variability of sorbitol in the investigated apricot cultivars ranges from 0.2 to $10.2 \mathrm{~g} / \mathrm{kg}$ with a mean value of 3.5 . These findings are in agreement with the literature, although the variations are higher than those reported by LO VOI and co-workers (1995). It is quite interesting that cultivars with the highest sucrose content ('Harcot', 'Hargrand' and 'Pellecchiella') demonstrate lower content of glucose and fructose. Fruits of cv. 'Sabbatani' inspite of subsequent chemical determination of high content of glucose and xylose were evaluated as very sour during the tastings. Such an estimate is explained by the fact that fructose was found to be sweeter than sucrose and sucrose sweeter than glucose (BASSI et al., 1996). Sorbitol probably has no special impact on the sweetness, and has the relative sweetness index of $50-60 \%$ if compared to sucrose (RAPAILLE et al., 1993). Initially, polyols like sorbitol and mannitol were used to sweeten food for diabetics. Alcohol sugar sorbitol has an advantage over sucrose in dietetic nutrition (RAPAILLE et al., 1993), because the different metabolism of sorbitol in comparison to other carbohydrates results in lower energetic input to the body. 
Organic acids are important constituents of fruit. Apart from being important organic metabolites (KAYS, 1991), they play a decisive role not only in the determining the quality of fruit and form but also important part in human diet (SHARMA \& NIGAM, 1992). The most important acids in apricot fruit are malic and citric acids, whereas fumaric acid is only a minor acid, contributing to the taste. The average content of citric acid $(11.6 \mathrm{~g} / \mathrm{kg})$ is in agreement with results reported by LO VOI and co-workers (1995), who found citric acid levels of $12.0 \mathrm{~g} / \mathrm{kg}$, whereas the malic acid levels $(18.9 \mathrm{~g} / \mathrm{kg})$ were higher than those reported by the same author $(11.8 \mathrm{~g} / \mathrm{kg})$. In appreciation of sensory qualities of apricots, acidity is a determining element of choice, especially as its level and alterability after picking will greatly modify the consumers' reactions. To characterize it, we have just used two criteria: $\mathrm{pH}$ and titratable acidity content, which correspond to the content of free organic acids in the pulp of fruit. Varieties having high free acidity and low level of total sugars would hardly be accepted by consumers, because cultivars with higher content of citric acid (cvs. 'Palummella, 'Pellecchiella', 'Tomcot' and 'Laycot') were more appreciated in testing panel than cv. 'Sabbatani', the latter with higher content of malic acid. Compared with citric acid, malic acid has a much stronger apparent acidic taste. From this point of view we could conclude that the optimal ratio between malic and citric acid is near the value of 0.8 .

\section{Conclusions}

Quality of a fruit is a subjective and complex parameter, therefore it is difficult to define, formulate and determine solid parameters, both in terms of production/marketing context and research. It is to be mentioned that only recently quality has been given a high priority as a price determinant by producers and consumers due to the combination of increased production, increased availability, and increasing consumer acquaintance.

Values from chemical analyses are useful for screening new cultivars and breeding selections for their potential acceptability, or for growers as targets to ensure that cultivation practice favourably affects fruit quality. In addition to the aforementioned objective parameters, in some countries other objective factors, which contribute to consumer preference, are considered important. These can include the combinations of the shape or form, the colour, the consistency of the pulp, the taste of the fruit that is often particular and closely linked to local habits and customs. Also, more attention should be given to correlating sensory evaluations and chemical composition of the fruit in order to identify the components that have major influences on consumer acceptance. 


\section{References}

ACKERMANN, J., FISCHER, M. \& AMADO, R. (1992): Changes in sugars, acids and amino acids during ripening and storage of apples (cv. Glockenapfel). J. agric. Fd Chem., 40, 1131-1134.

BASSI, D. \& SELLI, R. (1990): Evaluation of fruit quality in peach and apricot. Adv. hort. Sci., 4, 107-112.

BASSI, D., BARTOLOZZI, F. \& MUZZI, E. (1996): Patterns and heritability of carboxylic acids and soluble sugars in fruits of apricot (Prunus armeniaca L.). Plant Breeding, 115, 67-70.

BIELESKI, R. L. \& REDGWELL, R. J. (1985): Sorbitol versus sucrose as photosynthesis and translocation products in developing apricot leaves. Aust. J. Plant Physiol., 12, 657-668.

BROOKS, S. J., MOORE, J. N. \& MURPHY, J. B. (1993): Quantitative and qualitative changes in sugar content of peach genotypes (Prunus persica (L.) Batsch.). J. Am. Soc. hort. Sci., 118 (1), 97-100.

DOLENC, K. \& STAMPAR, F. (1998): Determining the quality of different cherry cultivars using HPLC method. Acta Horticulturae, 468, 705-712.

Doyon, G., Gaudreau, G., St-Gelais, D., Beaulieu, Y. \& Randall, C. J. (1991): Simultaneous HPLC determination of organic acids, sugars and alcohols. Can. Inst. Sci. Technol. J., 24 (1/2), 87-94.

FAUST, M. (1989): Physiology of temperate zone fruit trees. John Willey \& Sons, New York, pp. 1-46.

FÖLDHÁZI, G. (1994): Analysis and quantitation of sugars in honey of different botanical origin using high performance liquid chromatography. Acta Alimentaria, 23, 299-311.

HuDINA, M. \& STAMPAR, F. (1998): Saisonale Veränderungen von Zucker und organischen Säuren bei Birnen (Pyrus communis L.) cv. 'Williams Christbirne'. Krankheitsresistenz und Pflanzenschutz. Voraussetzung für die Qualitätsproduktion, XXXIII. Vortragstagung, 23-24 März 1998, Dresden, pp.191-196.

IBPGR (1984): Revised descriptor list for apricot (Prunus armeniaca L.). GUERRIERO, R. \& WATKINS, R. (Eds) Publ. by International board for plant genetic resources, Commission of European communities: Committee on disease resistance breeding and use of genebanks, IBPGR Secretariat, Rome \& CEC Secretariat, Brussels, pp. 25-26.

KAYS, S. J. (1991): Postharvest physiology of perishable plant products. An AVI Book, Publ. by Van Nostrand Reinhold, New York, pp. 157-161.

KOVÁCS, E. \& DJEDRO, G. A. (1994): Changes in organic acids of fruits after different treatments. Acta Horticulturae, 368, 251-261.

LO VOI, A., IMPEMBO, M. G., FASANARO, G. \& CASTALDO, D. (1995): Chemical characterization of apricot puree. J. Fd Comp. Anal., 8, 78-85.

MACRAE, R. (1981): Recent applications of high-pressure liquid chromatography to food analysis. $J$. $F d$. Technol.,16, 1-7.

MOLNÁR-PERL, I. \& MORVAI, M. (1992): Simultaneous gas chromatographic quantitation of sugars and acids in citrus fruits, pears, bananas, grapes, apples and tomatoes. Chromatographia, 34 (9/10), 502-504.

NigAM, V. N. \& SHARMA, S. D. (1987): Changes in the sugar content in developing apricot fruits cv. New Castle. Fruit Sc. Reports, 14 (3), 115-118.

RAPAILle, A., GOOSENS, J. \& HEumE, M. (1993): Sugar alcohols -in: MACRAE R. (Ed.) Encyclopaedia of food science, food technology and nutrition. Vol. 7., Academic Press, Harcourt Brace Jovanovich, Publishers London, San Diego, New York, Boston, Sydney, Tokyo, Toronto, pp. 4460-4464.

RIAZ, M. N. \& BuShwAY, A. A. (1994): Determinations of organic acids in raspberry cultivars grown in Maine. Fruit Varietes $J ., 48$ (4), 206-211

RiChMOND, M. L., BRANDAO, S. C. C., GRAY, J. I., MARKAKIS, P. \& STINE, C. M. (1981): Analysis of simple sugars and sorbitol in fruit by high performance chromatography. J. agric. Fd Chem., 29, 4-7. 
ROMAN, R. J. \& JENNINGS, W. G. (1971): Stone fruits -in: Hulme, A. C. (Ed.) The biochemistry of fruits and their products. Vol. 2., Academic Press, London and New York, pp. 411-436.

SHARMA, S. D. \& NIGAM, V. N. (1992): Changes in the organic acids of developing fruit and seed of apricot cv. New Castle (Prunus armeniaca L.). Agric. Sci. Digest, 12 (1), 21-24.

SHARMA, S. R. \& SHARMA, S. D. (1990): Studies on the physico-chemical changes during fruit development of some cultivars of apricot (Prunus armeniaca L.). Haryana J. Hort. Sci., 19 (1/2), 33-38.

WiLLIAMS, J. M., MARTIN, G. C. \& STAHLY, E. A. (1967): The movement and fate of sorbitol-C ${ }^{14}$ in the apple tree and fruit. J. Am. Soc. hortic. Sci., 90, 20-24.

WILLS, R. B. H., SCRIVEN, F. M. \& GREENFIELD, H. (1983): Nutrient composition of stone fruit (Prunus spp.) cultivars: apricot, cherry, nectarine, peach and plum. J. Sci. Fd Agric., 34, 1383-1389. 